症例

特発性血小板減少性紫斑病を合併したバセドウ病の 2 手術例 国立岡山病院外科

日井由行佐々木澄治松原㳯永広格

最近の11年間に手術を行ったパセドゥ病90例の5ち2例に特発性血小板减少性紫斑病 (ITP)を誌めた, ITP 合併パドウ病は猃断面，治療面で難沾することが多いと言われ ている，われわれの 2 例はITP が先行しており，ITPの治療に苦労したが，甲状腺重全 摘術による甲状腺機能の正常化と共に血小板数の增加が認められた。

甲状腺ホルモンと白血球数，血小板数との関係を調べるために，バセドウ病と甲状腺 畽場症例における自血球数，血小板数を比較検討したが，どちらも有意差は認めなかっ た.

しかし，ITP 合併バせドウ病では，甲状腺機能を正常化し，その結果として血小板数 を增加させるのに，甲状腺垔全摘術が有効な手段であると考える。

索引用語：バセドゥ病, 特発性血小板减少性紫斑病, 甲状腺要全摘術

はじめに

最近11年間に当科で手術を行っだ゙せドウ病は90例 で，そのうち2 例洔発性血小板減少性紫斑病（以下 ITP)の合併があった，六セドゥ病には慢性扁桃腺炎， 僧㟭弁逸脱症など種々の合併例す認められるが, ITP の合併例は猃断面・治㙩面でる難漇することが多い， われわれの 2 例も特にITPの治療に難浆したが, 甲状 腺垔全摘術後，血小板の増加が認められた，今回，ITP 合併ハセドウ病を中心にわれわれの経験を述へ，文献 的にす考察を加えた。 また，代せドウ病症例の白血球 数，血小板数を他の甲状腺腫瘍症例と比較険討した。

\section{症例}

\section{1.当科でのバセドウ病の手術例の検討}

1980年 4 月より1990年 3 月までの11年間に当科でく セドゥ病にて甲状腺亜全摘を施行したのは90例で，男

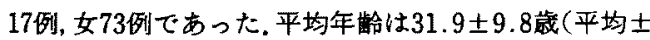
S.D.)であった，図1に年龄，性の分布を示す。生 90例の術前の併存疾患怙よび合併症を表 1 に示す，慢 性扁桃腺炎まは扁桃肥大が14例（15.6\%）と多く， 僧帽弁逸脱症が 7 例 (7.8\%)に認められた。 ITPは 2 例 (2.2\%) に認められた。 また，術前の抗甲状腺郕の 副作用と思われる顆粒球减少症か 5 例 $(5.5 \%$ )(無類 粒球症 1 例, 顆粒球減少症 4 例), 薬物性肝障害が 3 例 （3.3\%）に認められた，抗甲状腺剤に上る顆粒球減少

1991年 1 月 9 日受付 1992年 7 月 13日採用

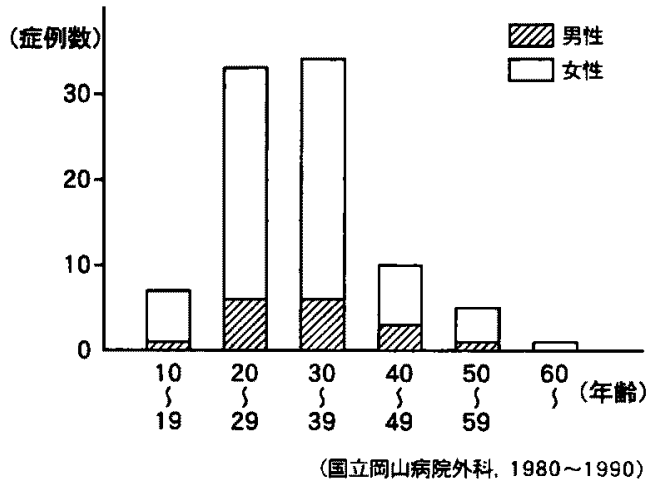

图1バセドウ病の年齢・性（手術症例；90例）

表】バセドウ病の術前の併存疾患およU゙合併症 (手術症例：90例)

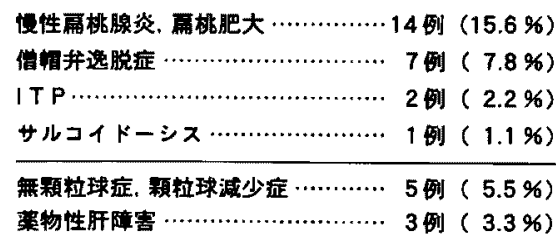

症 5 例之ITP 症例 2 例を除いたバセドウ病の白血球 数扣よび血小板数を他の甲状腺腫湢上比較してみた。 バセドゥ病では仼とんどの症例で入院後, 無機ヨード や $\beta$ ブロッカーなどを10日から 2 週間投与して術前 
処䈯を行っているので，初診時蛙よび手術直前の両者 の值を調べた，結果を表 2 に示すが，白血球数，血小 板数どちらもバセドゥ病の初診時，手術直前，他の甲 状腺腫瘍の 3 群間で有意差は認められなかった。

\section{ITP 症例}

症例 $1: 30$ 歳 (手術時), 女性.

家族歴，既往歴に特記すへきことはない，

1981年 6 月（23咸）両下肢に紫斑が出現した, 1982 年 6 月 (24歳) 鼻出血が出現し，当院内科にてITP と

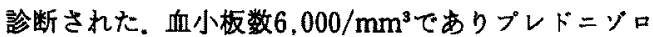
ンで治療が開始された.プレドニゾロンを最高 $100 \mathrm{mg} /$ day 用いたか，血小板数 $20,000 / \mathrm{mm}^{3}$ 以上に増加しな いため，1982年12月当院外科で摘脾術が施行された。 血小板数は術後よりしだいに增加し，最高28.4万/ $\mathrm{mm}^{3}$ に達し，以後ステロイドを漸減していった，血小 板数10〜20万/ $/ \mathrm{mm}^{3}$ が維持できた。 1984年 3 月にはス テロイドを中止した，1986年 2 月 6 日当院産婦人科で

\section{表 2 バセドク病の甲状腺碚症症例の白血球数书よU} 血小板数

\begin{tabular}{|c|c|c|c|}
\hline & $\begin{array}{c}\text { 白血球数 } \\
\left(/ \mathrm{mm}^{2}\right)\end{array}$ & $\begin{array}{c}\text { 血小板数 } \\
\left(\times 10^{\circ} / \mathrm{mm}^{2}\right)\end{array}$ & \\
\hline 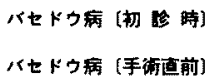 & $\begin{array}{l}5700 \pm 1600 \\
5800 \pm 1600\end{array}$ & $\begin{array}{l}25.6 \pm 8.4 \\
28.5 \pm 7.6\end{array}$ & $n=80$ \\
\hline 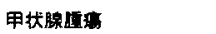 & $5600 \pm 1500$ & $25.1 \pm 6.1$ & $n=71$ \\
\hline
\end{tabular}

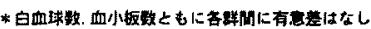

第一子を無事出産した，同年 2 月24日，軽度の甲状腺 の腫脹と眼球突出のため，模査を施行したところ甲状 腺譏能立進症か認められた，free T36.05pg/ml（正常 值2.7 5.9), free T4 18.0ng/dl（正常值0.78 2.11) であったので, MMI (メキマソール) 30mg/day 䦩 始した，その時の血小板数は14.4万/ $\mathrm{mm}^{3}$ であった。し かし，1988年 5 月（29葴）再び鼻出血が出現し，血小 板数 $5,000 / \mathrm{mm}^{3}$, 白血球数 $5,300 / \mathrm{mm}^{3}$ となり, 当院内 科に入院した，入院後 MMI を中止し，ブレ゙ニソロン を再開した，血小板数は変動しゃすく，ブレドニソロ ン5〜60mg/day のはかにビンデシン (VDS), ダナ ソール，ビタミンCb投与した。しかし，1989年2月

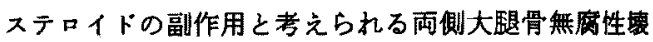
死を来したため，ステロイドを漸減せざるをえなく なった。また，ダナソールのためだと考えられる薬疹 る発現した。1989年 7 月になり甲状腺機能が元進して きたため MMI を投与したが，血小板数が減少するの でMMIを中止した，ステロイドを再開して血小板数 の上昇がみられ，甲状腺機能す低下していったが，骨 病変のため長期間は使用できず，ステロイドを潮惐し ていったところ，再び甲状腺機能がえ進してきた。 ピ タミンC投与により，血小板数は何とか維持でをた が、内科的コントロールが困難と判断し，1989年12月

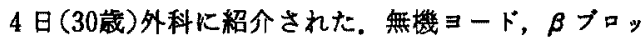
カーで衍前処置をして，12月18日甲状腺要全摘術を 行った，術後は，甲状腺機能は正常化し，血小板数は

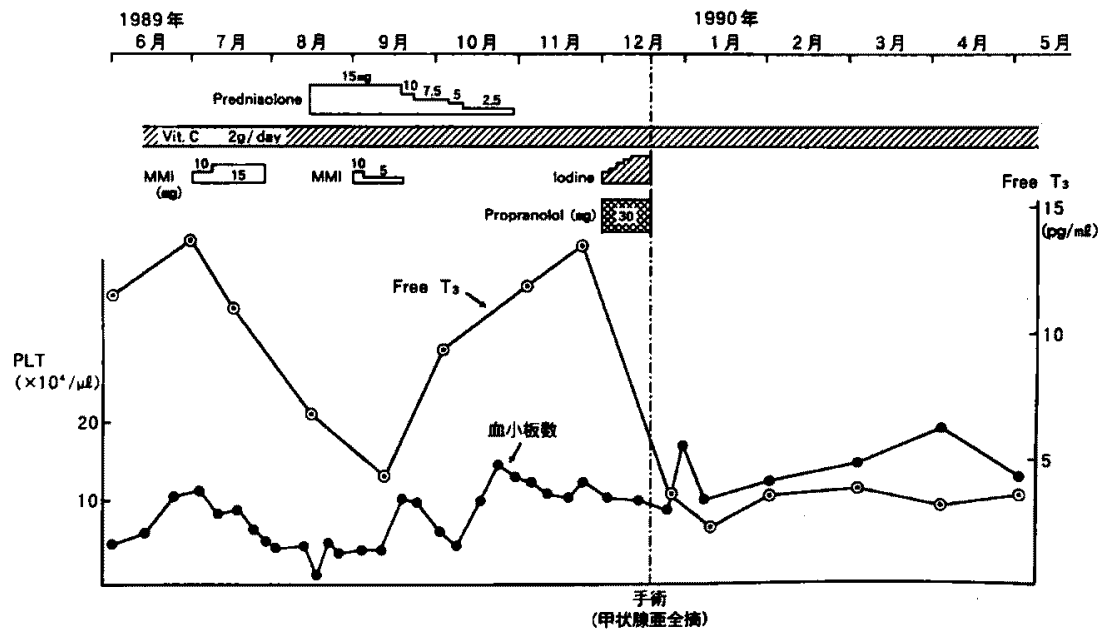

图 2 症例 1 の手術前後の経调

症例 1.30歳 (手衍時)，女性 
10 万 $/ \mathrm{mm}^{\mathrm{s}}$ 以上となり，1991年 3 月化至るまでステロ イドは中止しているが，経過は良好である（図2）。 症例 $2: 32$ 瓷（手術時)，女性.

既往歴には17歳の時，虫垂切除術がある，家矮歴に は特記すべきことはない。

1976年 5 月（28歳）のとき，濞出血があり，当院内 科でITP と診断され、ブレドニゾン $(5 \sim 30 \mathrm{mg} / \mathrm{day})$ の投与を受けていたところ，翌年 4 月，前頻部の尰脹 があり甲状腺機能六進症合併しているため, MMI （15 -30mg/day）む追加投与された．ITP，甲状腺機 能立進应ともに赛解, 增悪を繰り返したが, 特に, 蒋

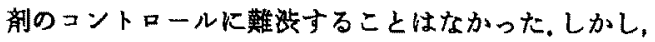
薬剤の副作用を危惧し，1980年12月10日 (32藏) 当科 で甲状腺垔全摘術を施行した，手衍時の血小板数は 6

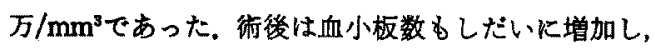
MMIは中止し，ステロイドを獑減していった．血小板 数す10万〜20万/ $/ \mathrm{mm}^{3}$ で安定していたので，1984年に はステロイド投与を中止した，1985年 2 月10日第一子 を出産した，程過を图 3 に示す，その後，当院内科で follow up しているが, 1989年7月, free T3 3.0pg/ $\mathrm{ml}$ (正常値2.7 5.9), free T4 $0.95 \mathrm{ng} / \mathrm{dl}$ (正常值 $0.78 \sim 2.11$ ), TSH $14.1 \mu \mathrm{IU} / \mathrm{ml}$ (正常値0.34 3.5), TRAb $8 \%$ ，血小板数 $38,000 / \mathrm{mm}^{3}$ であり，出血傾向 はなく，程過良好である。

\section{考察}

ITP と甲状腺㙨能元進症の合併例は1931年 Jacksonによって初めて報告されだ!. 以来, 現在までた100 例近くの報告例があり，本邦では現在までに約40例の 報告例がある2!

Evans ら3)は75例の ITP 症例に 4 例 (5.3\%)の甲状 腺機能穴進症を, Marshall ら4は42例の ITP症例に4 例 $(9.5 \%)$ の甲状腺機能元進症を認めている．当院で もITP 26例中 2 例 (7.7\%) のバセドウ病を認めてお り5),この 2 つ自己兔疫疾患の合併は稀なすのでは ない.

今回報告した 2 例のITPと甲状腺機能元進症の合 併例では, どちらすITPが先行していた，今回の症例 のよらにITPが先行すると、ステロイド投与のため甲 状腺機能六進症状態がマスクされ，バセドウ病の診断 が遅れたり、診断がついてり血小板减少症による紫琣， 出血傾向により抗甲状腺剤の投与に苦虑することがあ る.

症例 1 では約 4 年半経ってからバセドウ病が発見さ れたか，血小板数の維持が非常に困難であり，薬剂の 副作用屯現れ，ITP，バドウ病どちらに対しても十分 な内科的にコントロールができなかった。しかし，甲 状腺垔全摘術後は血小板数が自然に回得した，症例 2 では、薬珴によるコントロールはらまくいっていたが， 3 年後に甲状腺亜全摘術を施行し，血小板数が増加し

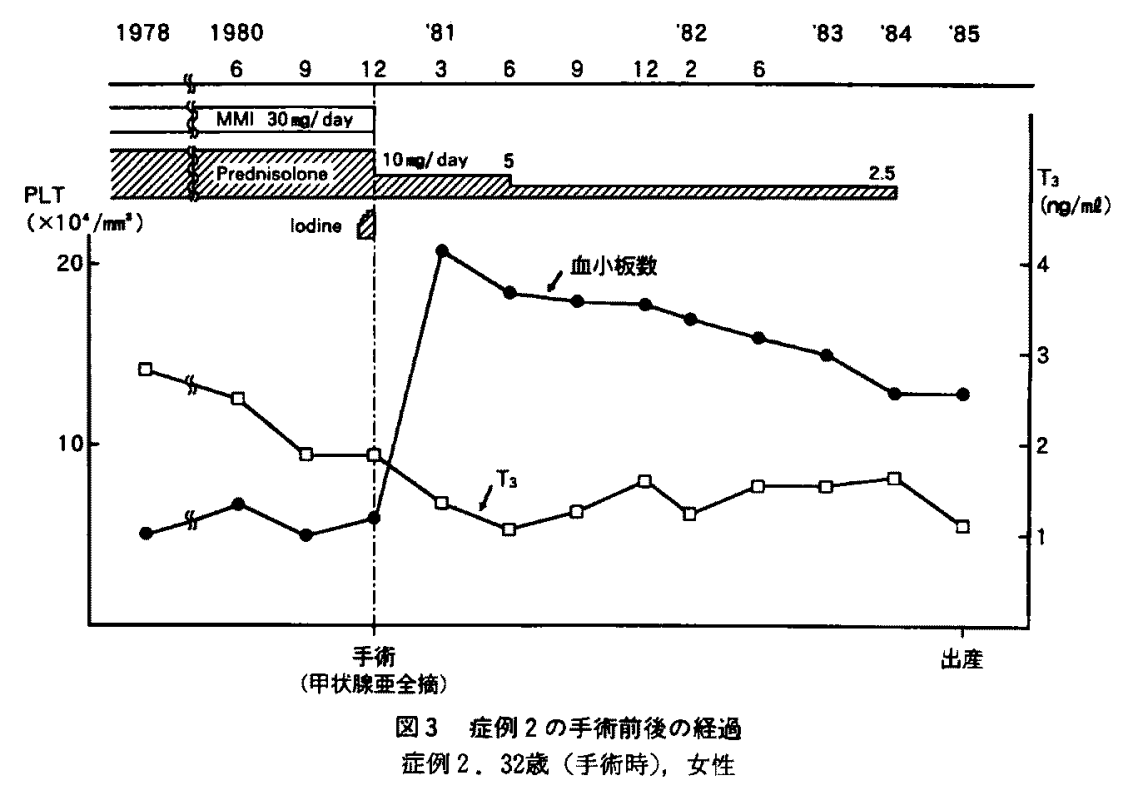


てステロイドを中止することができ，正常児をるうけ ることができた。

ITP とバセドゥ病の合併例では，血小板数を正常化 するためにすず甲状腺機能を正常化することが必要で あると言われている67n. それは，甲状腺機能立進症が 血小板数減少を引き起こしていると推測されているか らである，現に，Herman らはパゼゥ病と血小板減 少症の合併例49例のらち、バセドウ病を治療して euthyroid になったとき18例（82\%)で血小板数が正常化し たとしている゙，また，越野らの集計では，バセドウ病 と ITP の合併例36例で, 甲状腺機能の正常化により血 小板数が回復したものが26例 (72\%)あっだ). 倉田ら はラットを用いた実験で甲状腺ホルモンが血小板寿命 を短縮するといら結果をえており，臨床でるバセドウ 病患者214例中，治療を受けていない患者の43\%は血小 板数が15万/mm以下であったが，治療後では $6 \%$ \%で あったと報告している゙。

今回, われわれがパドゥ病90例の術前の血小板数,

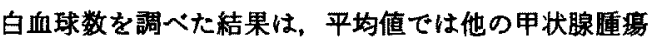
症例との間にどちらも差はなく，ITP症例を除いて血 小板数 15 万 $/ \mathrm{mm}^{3}$ 以下だったのは 2 例 $(2.2 \%)$ のみで あった（表 2 )。

しかし，バセドゥ病の血小板の寿命は短樎している との報告があること间，またわれわれの 2 例において 甲状腺雷全摘㭪後に血小板数の自然堌加が起こって拧 ク，血小板の減少に甲状腺ホルモンがなんらかの影響 を与えているようである。

われわれの経験した 2 例のITP とバセドウ病の合 併症例では，甲状腺機能の正常化により血小板数が正 常化したが，甲状腺機能を正常化するうえで甲状腺严 全摘術は薬玮の副作用を危惧するよ5な症例ては有効 な手段であると考えられる。

\section{結語}

ITP を合併したバセドウ病 2 例を経験した，どちら の症例も ITPが先行していた，本症に括いて性血小板
数を正常化するのにバセドウ病の治療が重要であり， それには甲状腺重全摘御が有効であると思われる。

\section{女 献}

1) Jackson AS: Acute hemorrhagic purpura with esophthalmic goiter. JAMA $96: 38,1931$

2）吉沢 要，鉿木陽一，今井俊輔他：バセドゥ病と特 発性血小板減少性紫班症の合併した 1 例。臨血 $23: 185,1982$

3) Evans H, Perry KMA: Thrombocytopenic purpura. Lancet 2: 410-413, 1943

4) Marshall JS, Weisherger AS, Levy RP, et al: Coexistent idiopathic thrombocytopenic purpura and hyperthyroidism. Ann Int Med $67: 411$ $-414,1967$

5）瀨崎達雄，小谷重光，深井待子：難治性僈性 ITP の治療上予後．厚生省特定疾患特発性造血障害調 查研究班，平成元年度研究業纊報告書，p128-129

6）藤㱦 滋，天野定堆，黑須康彦他：特発性血小板減 少性紫斑病様の血小板减少をきたしたバセドウ病 の 1 例，内分渓外科 6:209-213, 1989

7) Herman J, Resnitzky P, Fink A: Association between thyrotoxicosis and thrombocytopenia. A case report and review of the literature. Isr J Med Sci $14: 469-475,1978$

8）越野健，岸田 繁，原田実根他：抗甲状腺刘単独 投与により治㞠しだ゙セドゥ病合併血小板诚少性 紫玫病の 1 例, 内科 $54: 979-982,1984$

9) Kurata $Y$, Tsubakio $T$, Kitani $T$, et al: Thrombocytopenia in Graves' disease : Effect of $T_{s}$ on platelet kinetics. Acta Haematol $63: 185$, 1980

10) Lamberg BA, Kivikangas V, Pelkonen $R$, et al : Thrombocytopenia and decreased life-span of thrombocytes in hyperthyroidism. Ann Clin Res $3: 98-102,1971$ 


\title{
TWO CASES OF GRAVES' DISEASE ASSOCIATED WITH IDIOPATHIC THROMBOCYTOPENIC PURPURA
}

\author{
Yoshiyuki USUI, Sumiji SASAKI, Jun MATSUBARA and Itaru NAGAHIRO \\ Department of Surgery, National Okayama Hospital
}

In a recent 11-year period, we had two cases of Graves' disease associated with idiopathic thrombocytopenic purpura (ITP) among ninety operated cases of Graves' disease. It is often pointed out that the diagnosis and treatment of Graves' disease associated with ITP are very difficult. In these 2 cases experienced, Graves's disease was preceded by ITP, and we had difficulties in controlling ITP. However, when the thyroid function was normalized by subtotal thyroidectomy, the platelet count increased.

To study the correlation between the thyroid function and white cell and platelet counts, the both counts were comparatively analized in patients with Graves' disease and those having a thyroid tumor. There was no statistical difference between them.

It is, however, concluded that subtotal thyroidectomy might be an effective procedure to normalize the thyroid function and to increase the platelet count subsequently in the patients with Graves' disease associated with ITP. 